\title{
The Role of Work Stress in Mediating Workload and Work Environment on Crew Performance PT. Indonusa Tenggara Marine
}

\author{
I Komang Budiasa*, I Made Sara, Ni Wayan Siramiati \\ Magister of Management, Postgraduate Program, Warmadewa University, Denpasar, Bali-Indonesia \\ *mangbudiasa80@gmail.com
}

\begin{tabular}{l}
\hline Published: 19/03/2021 \\
How to cite (in APA style): \\
Budiasa, I, K., Sara, I, M., Siramiati, N. W. (2021). The Role of Work Stress in Mediating Workload and Work \\
Environment on Crew Performance PT. Indonusa Tenggara Marine. Jurnal Ekonomi dan Bisnis \\
Jagaditha, Vol (No), 61-70. doi: https://doi.org/10.22225/jj.8.1.3124.61-70
\end{tabular}

\begin{abstract}
Performance is the result of work seen form the quality and quantity achieved by an employee in carrying out his duties in accordance with the given responsibilities assigned to him. Work stress is a condition of tension that affects the emotions, thought processes and physical condition of an employee. Work stress arises where work demands exceed the person's capacity to cope, moreover an employee's self-discomfort to the surrounding work environment. This study aims to determine the role of work stress in mediating of workload and work environment on crew performance. There were 31 crews of PT. Indonusa Tenggara Marine who participated as the sample of study. Those sample was chosen using nonprobability sampling with saturated sampling method. Data analyzed using descriptive analysis and inferential analysis. Hypothesis tested using the Partial Least Square (PLS) application. The results showed that the workload had a positive and insignificant effect on crew performance, work environment had a positive and insignificant effect on crew performance, workload had a positive and significant effect on work stress, work environment had a negative and significant effect on work stress, work stress had a negative and significant on crew performance, the effect of workload and work environment on crew performance has been perfectly mediated by work stress.
\end{abstract}

Keywords: Workload, Work Environment, Work Stress, Crew Performance

\section{INTRODUCTION}

Human resources with good performance and qualified are expected to encourage achievement of competitive advantage from the organization. Other than that, in order to achieve these goals required performance demands and increase performance of each individual. High performance makes employees are increasingly loyal to the organization, motivated and will enjoy work, sometimes it can cause individuals to be unable to escape from job pressure at hand. Work pressure when it occurs continuously can cause various things including work stress. Stress can affect employee performance and become the biggest problem in world today (An et al., 2020).

Excess stress if managed properly will certainly have a good impact and can be adapted to the work environment (Khuong \& Yen, 2016). Stress reactions are commonly seen from a physiological, psychology aspect and individual behavior (Beehr in Angwen, 2017). An individual is categorized as experiencing work stress if the stress experienced involves the surrounding environment or a person's inability to meet job demands (Luthans in Yoga et al., 2018).

One of the factors of less productive employee performance is due to work stress, supported by research Alkubaisi (2015) states that work stress has a negative and huge impact on employee performance in Qatar banking sector. Employee who experienced too much stress can interfere with their abilities to carry out work and face the work environment (Hatmawan, 2015). However, different results were obtained by Chandra \& Adriansyah (2017) where work stress with performance has a beneficial outcome. Bahri et al. (2018) did not find any significant effect of work stress to employee performance. 
Greenberg (Angwen, 2017) states that one source of work stress is heavy workload and poor physical environmental conditions. Workload arises from interaction between task demands, work environment in which employee are placed, skills they have, the behavior and perceptions of employees (Susiarty et al., 2019). Workload is an important contributor to stress, depending on every individual facing it. Workload also affects employee motivation and performance (Siswanto et al., 2019).

Shabbir \& Naqvi (2017) explain that workload and work complexity altogether affect work stress, while work stress contrarily affects performance. Alkubaisi (2015) also states that workload fundamentally affects work stress of employees in the Qatar banking sector. The insignificant results of the study between workload and work stress were found in the research of Lestari \& Ratnasari (2018). Meanwhile, Johari et al. (2018) stated that workload had no effect on performance.

Work environment is something around workers and affects workers in carrying out their duties (Nitisemito in Erawati et al., 2019). The work environment is one of the considerations for employees at work, employees will be able to carry out their work properly if supported by good environmental conditions. Putra \& Rahyuda (2015) research states that the work environment has a negative and significant effect on work stress. Dharmanegara et al. (2016) stated that the work environment has a positive effect on employee performance.

The crew is the spearhead in the operational activities of the shipping company PT. Indonusa Tenggara Marine. Work stress is a syndrome that affects all workers and mostly affects productive workers (Hastutiningsih, 2019). An et al. (2020) states that seafarers are a profession with highrisk job and are exposed to certain working conditions and situations that cause work stress symptoms.

Physical and administrative activities on board are still very dominant when the ship is conducting surveys or other ship maintenance activities. Both physical and administrative workloads can put pressure on crew member. Work on ships is certainly exposed to unfavorable conditions such as hot working temperatures, noise, vibrations, irregular working hours which negatively affect the health condition and performance of the crew. Limited communication facilities, monotonous routines and activities can make the crew feel bored if the crew cannot manage time and activities properly. Covid-19 pandemic that occurred had an impact on the conditions and activities of the crew, starting from implementing health protocol procedures in the ship and working area, restricting access, obligation to carry out medical examinations and self-quarantine procedures.

This phenomenon can cause work stress on crew by showing symptoms such as frequent daydreaming, difficulty in concentrating, not focus on work, not being enthusiastic at work and sometimes breaking rules on the board. Symptoms and work stress conditions if allowed to continue will affect the health and performance of the crew, in the end can disrupt the operational activities and safety on board. The crew performance of PT. Indonusa Tenggara Marine shows an indication that it is not optimal. The working day rate of the crew in 2019 appears to fluctuate every month, the average attendance rate for crew is 3.09 percent, it means that the level of crew absences is high.

Based on the phenomena and gaps in previous research studies, the purpose of this study to determine the effect of workload and work environment on work stress and crew performance PT. Indonusa Tenggara Marine.

\section{CONCEPTS AND HYPOTHESIS \\ Workload, Work Environment and Crew Performance}

Campbell's theory (Boxall et al., 2007) considers performance as a behavior or action relevant to the achievement of scalable and measurable organizational goals. Performance as a person's ability to carry out a job with existing resources (Johari et al., 2018), to do the work and the results achieved from that work (Wibowo, 2017).

Kasmir (2019) states workload as a ratio between the total raw time to complete tasks and work to the total standard time. Workload is an element that must be considered in order to get harmony and high work productivity, which can reduce performance (Siswanto et al., 2019). Shabbir \& Naqvi (2017) conducted a study on Travel Bureau employees in Pakistan which stated that an increase in workload led to a decrease in performance. It is emphasized in Gozali (2016) research that workload has a 
negative effect on employee performance of Central Bureau of Statistics in Deli Serdang and Sedang Berdagai Regency. Putri \& Rahyuda (2019) also stated that workload has a negative effect on employee performance.

Nitisemito (Al-Omari \& Okasheh, 2017) stated that the work environment is everything around the worker which can affect the results of the work. A good work environment will encourage individuals or groups to work better at work (Putra \& Rahyuda, 2015) and be able to be positive at work (Hatmawan, 2015) and can help increase productivity levels and employee performance (Tjibrata et al., 2017). Research of Dharmanegara et al. (2016) and Tjahjaningsih et al. (2019) also found that the work environment has a positive and significant effect on performance.

Based on theoretical and empirical studies, therefore the following hypothesis is formulated. H1: Workload has a negative and significant effect on crew performance.

H2: Work environment has a positive and significant effect on crew performance.

\section{Workload, Work Environment, Work Stress and Crew Performance}

Work stress as a response of people when demands and work pressures are not in accordance with their knowledge and ability to cope with it (Ekawarna, 2018). Workloads that are not comparable to ability, availability of time, not suitable with experience and competence, as well as risky work are problems that are often faced in the work environment and triggers work stress (Zulmaidarleni et al., 2019). Low task demands can cause boredom and apathy towards employees, while excessive task demands can cause tension and anxiety (Ekawarna, 2018). Alkubaisi (2015) found that excess workload causes work stress on employees. Angwen (2017) found that workload is positively related to the work stress of PT. Panggung Citrabuana Electric employee.

Stress that is not handled properly will affect a person's inability to interact positively with the work environment (Siagian, 2018). Good conditions of work environment will have an effect on reducing employee work stress. It is emphasized by Putra \& Rahyuda (2015) research that physical work environment has a significant negatif effect in work stress. Another study that is in line is Bahri et al. (2018) where the comfortable work environment will affect the degree of work stress.

Excessive work stress can disrupt performance (Ekawarna, 2018). Stress that exceeds tolerance limit and employee's ability can have an impact on employee performance decline (Susiarty et al., 2019). Ahmad et al. (2018) found that work stress made the performance of Emergency care Unit Nurse in Makassar decrease. Reaffirmed in the research of An et al. (2020) where work stress is negatively related to seafarer performance.

Based on theoretical and empirical studies, therefore the following hypothesis is formulated. H3: Workload has a positive and significant effect on crew work stress.

H4: Work environment has a negative and significant effect on crew work stress.

H5: Work stress has a negative and significant effect on crew performance.

H6: Work stress mediates the effect of workload on crew performance.

H7: Work stress mediates the effect of work environment on crew performance.

The conceptual framework proposed in this study is the relationship between workload, work environment and work stress and crew performance. The conceptual framework is presented in Figure 1 below.

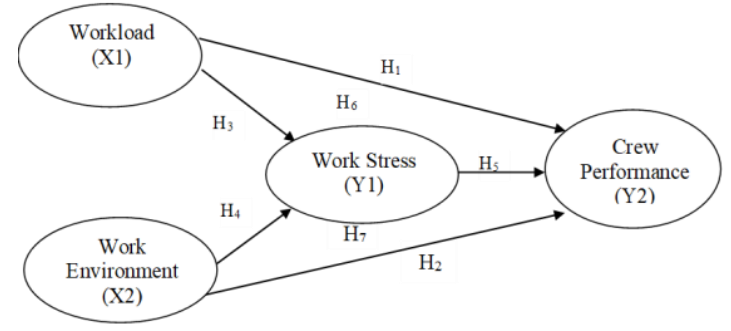

Figure 1

Framework Research

\section{METHOD}

This research is explanatory research. The population in this study were all crew members who worked on vessels owned by PT. Indonusa Tenggara Marine. There were 31 crew who participated as the samples of study. Those sample were chosen using nonprobability sampling with saturated sampling. Data analyzed using Partial Least Square (PLS), which is one of the variant-based structural equation analysis methods.

\section{RESULT AND DISCUSSION}




\section{Characteristics of Respondents}

The results of research on 31 respondents of PT. Indonusa Tenggara Marine, it is known that the characteristics of the most respondents are aged of 31-40 years with a work period of 1-5 years and the last education at Senior High School / Vocational School level.

\section{Validity Test}

The test results show that all indicators used to reflect the construct have a correlation value greater than 0.30 and significant at the 0.05 (Sugiyono, 2019).

\section{Reliability Test}

The reliability test results show that the Cronbach Alpha value in the Workload construct (X1) is 0.924, the Work Environment construct (X2) is 0.952 , the Work Stress construct (Y1) is 0.962 and the Crew Performance construct (Y2) is 0.912. All indicators used to reflect the construct are reliable, where the Cronbach Alpha value of each construct were greater than 0.60 (Tharenou et al., 2007).

\section{Description of Crew Performance Variable}

The average score for crew performance variable is 3.56. The highest respondent average score of 3.71 for quality indicator. While the lowest score of 3.42 for the quantity and effectiveness indicator.

\section{Description of Work Stress Variable}

The average score of work stress variable is 2.65 , it means that the work stress of the crew members of PT. Indonusa Tenggara Marine in the medium category. The highest respondents average score of 2.77 for psychological indicators, while the lowest average score of 2.55 for behavioral indicator.

\section{Description of Workload Variable}

The average score of the workload variable is 2.59 , it means the workload of crew member of PT. Indonusa Tenggara Marine in the low category. The highest respondent average score of 2.77 for the performance indicator, while the lowest average score 2.39 for temporal demand indicator.

\section{Description of Work Environment Variables}

The average score of 3.66 for work environment variable, it means work environment in the good category. The highest average score of 3.77 for the work facility indicator, while the lowest average score of 3.58 for the relationship between co-workers indicator.

\section{Measurement Model (Outer Model) Convergent Validity}

The result of test in Figure 2 showed loading factor values were greater than 0.70 and $\mathrm{T}$ statistics value greater than T-Table, indicate that all construct indicators are valid. The result of test can be seen in Figure 2 and Figure 3.

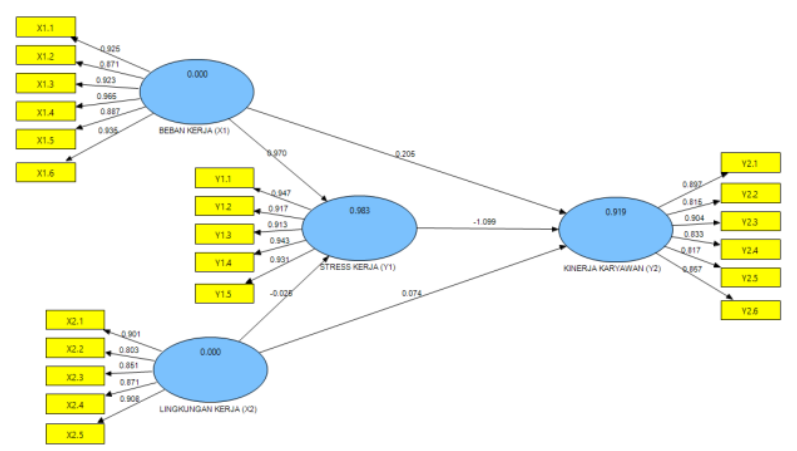

Figure 2

Outer Loading and Path Analysis

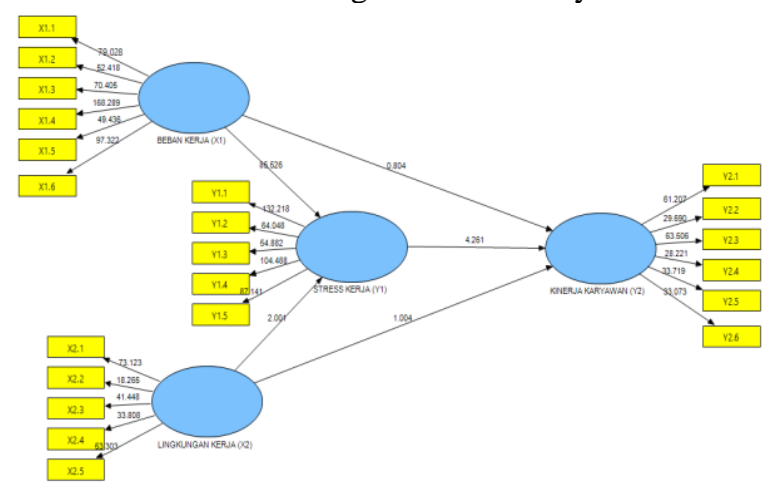

Figure 3

Bootstrapping

\section{Discriminant Validity}

Cross loading calculation shows that cross loading index value of all indicators in each construct is greater than the index value of other indicators on other constructs in one block. The result of cross loading value above of the threshold value 0.50 which indicated the variable in this study have good discriminant validity.

\section{Composite Reliability and Cronbach Alpha}

The test results show that the value of the composite reliability of the Workload construct (X1) is 0.970 , the Work Environment (X2) is 
0.938, the Work Stress (Y1) construct is 0.970 and the Crew Performance construct (Y2) is 0.942. The Cronbach Alpha value of the Workload construct (X1) is 0.962 , the Work Environment (X2) is 0.918, the Work Stress construct (Y1) is 0.961 and the Crew Performance construct (Y2) is 0.926. All construct based on composite reliability and Cronbach Alpha showed value above 0.70, so overall construct and instruments are declared reliable.

\section{Structural Model (Inner Model)}

Evaluation of Structural Model based on $R$ Square $\left(R^{2}\right)$

Result of $R$ Square $\left(R^{2}\right)$ value of 0.983 , for work stress fit into the strong model criteria, it means variations in workload and work environment able to explain the variations in work stress by 98.3 percent and the remaining 1.7 percent explained by variations in other variables outside the model. Meanwhile, crew performance has R Square (R2) value of 0.919 fit into strong model, it means workload, work environment and work stress able to explain the variation in crew performance by 91.9 percent, while the remaining 8.1 percent is explained by other variables.
Evaluation of Structural Model based on $Q$ Square Predictive Relevance $\left(Q^{2}\right)$

The results of Q Square Predictive Relevance value of 0.999 based on the criteria of Ghozali \& Latan (2014) fit into strong criteria. It can also mean that 99.9 percent of the crew performance construct can be predicted by variations in the workload construct, work environment and work stress.

\section{Evaluation Structural Model based on Goodness of Fit ( GoF)}

To calculate this GoF value, the average of $\mathrm{R}^{2}$ value of 0.951 while the average AVE value of 0.798 , then the GoF value is $\sqrt{ } \mathrm{AR}^{2} * \sqrt{ } \mathrm{A} . \mathrm{AVE}=$ $\sqrt{ } 0.951 * \sqrt{ } 0.798=\sqrt{ } 0.758=0.871$, it means the global model has a large predictive.

\section{Path Analysis and Hypothesis Testing}

Path analysis and hypothesis testing is expected to reject $\mathrm{H} 0$ or sig $<0.05$ ( $\mathrm{T}$ statistic $>$ 1.96 with a significant level of 0.05). Path analysis can be seen in Table 1, analyzing the relationship between workload, work environment, work stress and crew performance.

Table 1

Path Analysis and Hypothesis Test

\begin{tabular}{|l|c|c|c|c|c|}
\hline \multicolumn{1}{|c|}{ Construct } & $\begin{array}{c}\text { Path } \\
\text { Coefficient }\end{array}$ & T-Statistics & Hyphotesis & T-Table & Description \\
\hline $\begin{array}{l}\text { Workload (X1) -> Crew } \\
\text { Performance (Y2) }\end{array}$ & 0,205 & 0,804 & H1 & 1,96 & $\begin{array}{c}\text { Not } \\
\text { Significant }\end{array}$ \\
\hline $\begin{array}{l}\text { Work Environment (X2) -> } \\
\text { Crew Performance (Y2) }\end{array}$ & 0,074 & 1,004 & H2 & 1,96 & $\begin{array}{c}\text { Not } \\
\text { Significant }\end{array}$ \\
\hline $\begin{array}{l}\text { Workload (X1) -> Work } \\
\text { Stress (Y1) }\end{array}$ & 0,970 & 85,526 & H3 & 1,96 & $\begin{array}{c}\text { Positive } \\
\text { Significant }\end{array}$ \\
\hline $\begin{array}{l}\text { Work Environment (X2) -> } \\
\text { Work Stress (Y1) }\end{array}$ & $-0,025$ & 2,001 & H4 & 1,96 & $\begin{array}{c}\text { Negative } \\
\text { Significant }\end{array}$ \\
\hline $\begin{array}{l}\text { Work Stress (Y1) -> Crew } \\
\text { Performance (Y2) }\end{array}$ & $-1,099$ & 4,261 & H5 & 1,96 & $\begin{array}{c}\text { Negative } \\
\text { Significant }\end{array}$ \\
\hline
\end{tabular}

Source: Data processed 2020

The path coefficient of the direct effect of workload on performance is 0.205 with a $\mathrm{t}$ statistic value of 0.804 smaller than the t-table $(0.804<1.96)$, proving that workload has no significant positive effect on crew performance.

The path coefficient of direct effect of the work environment on crew performance is 0.074 with a t-statistic of 1.004 smaller than the t-table
(1.004 < 1.96 which indicated that work environment has no significant positive effect on crew performance.

Workload has a significant positive effect of 0.970 on crew work stress with a t-statistics 85.526 greater than the t-table value (85.526> 1.96). 
Work Environment has a significant negative of -0.025 on crew work stress with a t-statistics value of 2.001 greater than the t-table value (2.001> 1.96).

Path coefficient of direct effect of -1.099 for work stress on crew performance with a tstatistics value 4.261 greater than t-table value
(4.261> 1.96), which indicated work stress has a significant and negative effect on crew performance.

\section{The Role of Mediation}

The results of the mediation role test are shown in Table 2.

Tabel 2

Mediation Role

\begin{tabular}{|c|c|c|c|c|c|c|}
\hline \multicolumn{3}{|c|}{ Variables } & \multirow{2}{*}{ Hypothesis } & \multicolumn{2}{|c|}{ Koeficient } & \multirow{2}{*}{ Mediation } \\
\cline { 5 - 6 } & Exogenous & Direct Effect & Indirect Effect & \\
\hline $\begin{array}{c}\text { Workload } \\
\text { (X1) }\end{array}$ & $\begin{array}{c}\text { Work Stress } \\
\text { (Y1) }\end{array}$ & $\begin{array}{c}\text { Crew } \\
\text { Performance } \\
\text { (Y2) }\end{array}$ & H6 & $\begin{array}{c}-0,947 \\
\text { t-statistik } \\
106,698 \\
\text { (Significant) }\end{array}$ & $\begin{array}{c}0,179 \\
\text { t-statistik 0,652 } \\
\text { (Not Significant) }\end{array}$ & $\begin{array}{c}\text { Perfect } \\
\text { Mediation }\end{array}$ \\
\hline $\begin{array}{c}\text { Work } \\
\begin{array}{c}\text { Environment } \\
\text { (X2) }\end{array}\end{array}$ & $\begin{array}{c}\text { Work Stress } \\
\text { (Y1) }\end{array}$ & $\begin{array}{c}\text { Crew } \\
\text { Performance } \\
\text { (Y2) }\end{array}$ & H7 & $\begin{array}{c}0,824 \\
\text { t-statistik } \\
27,417 \\
\text { (Significant) }\end{array}$ & $\begin{array}{c}0,069 \\
\text { t-statistik 0,977 } \\
\text { (Not Significant) }\end{array}$ & $\begin{array}{c}\text { Perfect } \\
\text { Mediation }\end{array}$ \\
\hline
\end{tabular}

Source: Data processed 2020

\section{DISCUSSION}

The Effect of Workload on Crew Performance PT. Indonusa Tenggara Marine

The result shows that workload has a positive and insignificant effect on crew performance. It means that workload does not significantly increase crew performance. Thus, hypothesis which states that workload has a negative and significant effect on crew performance is not proven.

The insignificant effect due to the perception of respondents with the lowest average score on the indicators of completing work in accordance with the predetermined time, completing of work on time is not prioritized by the crew, but minimizing errors, negative impact and safety onboard are preferred. Another factor is all crew members who work onboard PT. Indonusa Tenggara Marine has the expertise and competence as a crew, so that the crew knows the workload on board. The age majority of crew at PT. Indonusa Tenggara Marine is 31-40 years old who are still of productive age and are supported by experience working as a seafarer who already understands the conditions of the workload onboard. So that the workload factor is not one of the factors that affect crew performance.

The findings of this study contrary to other studies such as Shabbir \& Naqvi (2017), Akob (2016), Gozali (2016), Putri \& Rahyuda (2019) and Hastutiningsih (2019) which stated that workload has a negative effect on performance. The results of this study support the research of Chandra \& Adriansyah (2017), Johari et al. (2018) and Susiarty et al. (2019) where workload has no significant effect on employee performance.

The results of this study opposite of Ekawarna (2018) where stated that excessive task demands cause employee tension and anxiety which affects employee motivation and performance. Wibowo (2017) also states a theory that is not in line with the results of research where an increase in workload causes employee productivity to decrease. Workload is reflection of the productive work time or productivity of an employee in a certain time.

The Effect of Work Environment on Crew Performance PT. Indonusa Tenggara Marine

The results showed work environment had a positive and insignificant effect on crew performance, it means that the work environment does not have an impact on improving crew performance of PT. Indonusa Tenggara Marine. Thus, the hypothesis states that the work environment has a positive and significant effect on crew performance is not proven.

The insignificant effect caused by the relationship with co-workers who have the lowest value according to the respondent's perception. Limitations and routine work of crew can make 
relationships with coworkers less conducive. Another factor is the characteristics of respondents are dominated by the age of 31 to 40 years old is categorized as productive age, experience as a seafarer and length of working at PT. Indonusa Tenggara Marine so that the crew knows the conditions of their work environment and has adapted to the work environment.

The results of this study contrary to other research such as Dharmanegara et al. (2016), Yugusna et al. (2016), Tjibrata et al. (2017), Harini \& Kartiwi (2018), Tjahjaningsih et al. (2019) and Susiarty et al. (2019) which stated that the work environment has a positive influence on performance, a comfortable and conducive work environment has an impact on performance. This study supports previous research including Hamid \& Hassan (2015), Erawati et al. (2019) and Hastutiningsih (2019) show that work environment having a positive and insignificant effect on performance.

The results contradict the theory presented by Nitisemito (Al-Omari \& Okasheh, 2017) where the work environment can affect the employee work due to work results is one of the indicators of employee performance. Sutrisno (2019) statement is also opposite with this study which stated that employee performance in an organization influenced by work environment.

\section{The Effect of Workload on Crew Work Stress PT. Indonusa Tenggara Marine}

The results showed that workload has a positive and significant effect on crew work stress. It means that the increasing workload of crew will significantly increase crew work stress and vice versa. Therefore, the hypothesis which states that workload has a positive effect on crew work stress can be accepted.

The results of this study supported by previous studies such as Alkubaisi (2015), Hatmawan (2015) Shabbir \& Naqvi (2017), Angwen (2017) and Zulmaidarleni et al. (2019) stated that workload has a negative effect on work stress. The results of this study in line with Ekawarna (2018) theory which states that excessive task demands can cause tension and anxiety which is one of the characteristics of work stress. Wibowo (2019) also supports this study where one of the causes of work stress is excessive workload.

The Effect of Work Environment on Crew Work Stress PT. Indonusa Tenggara Marine
The result of the effect of work environment on crew work stress showed a negative and significant effect. It means that better work environment of the crew, the crew work stress will be low and vice versa. Therefore, the hypothesis which states work environment has a positive and significant effect on work stress can be accepted.

The results of this study supported by previous studies such as Putra \& Rahyuda (2015), Kristanti (2017), Angwen (2017), Bahri et al. (2018) Zulmaidarleni et al. (2019) and Susiarty et al. (2019) that work environment has a negative and significant effect on work stress. This result is consistent with the statement of Robbins \& Judge (2019) where the environment plays a role in the emergence of work stress, stress is caused by the inability of an employee to face his work environment. Siagian (2018) also states that work stress is caused by a person's inability to interact positively with the work environment, so that a condition of tension appears that affects emotions, thoughts and physical conditions.

\section{The Effect of Work Stress on Crew Performance PT. Indonusa Tenggara Marine}

The results of the effect of work stress on crew performance showed a negative and significant effect. It means that an increased in work stress can have an impact on decrease in crew performance, while reduction in work stress can improve crew performance. Therefore, the hypothesis which states work stress has a negative and significant effect on crew performance can be accepted.

The results of this study are in line with previous studies done by Alkubaisi (2015), Ahmad et al. (2018), Susiarty et al. (2019), An et al. (2020), Erawati et al. (2019) and Hastutiningsih (2019) that work stress has a negative effect on performance, excessive work stress makes employee performance decrease. Result of this study is certainly supported by the statement of Robbins \& Judge (2019) where excessive stress experienced by a person can give unattainable demands resulting in low performance.

The Role of Work Stress in Mediating Workloads on Crew Performance PT. Indonusa Tenggara Marine

The results of testing the role of work stress to mediate the effect of workload on crew 
performance showed that work stress acts as a complete mediation of workload on crew performance. The existence of work stress variables causes the effect of workload on performance to decrease or previously was significant to be insignificant. It means that work stress able to perfectly explain the reasons why workload affects crew performance. Therefore, the hypothesis which states work stress mediates the workload on crew performance is proven.

The results of this study supported by previous studies such as Shabbir \& Naqvi (2017), Abbasi \& Janjua (2016), Putri \& Rahyuda (2019), Hastutiningsih (2019) and Yosiana et al.(2020) which states work stress as a mediator between workload and crew performance.

The Role of Work Stress in Mediating Work Environment on Crew Performance PT. Indonusa Tenggara Marine

The test results showed work stress as a perfect mediation (complete mediation) of work environment on crew performance. The results showed that work stress can perfectly explain the reasons why work environment affects performance, the relationship between work environment and performance is strengthened by the presence of work stress. A good work environment can create good working conditions so that with low stress it can improve crew performance. Therefore, the hypothesis which states work stress mediates the work environment on crew performance is proven.

This finding supported by previous studies such as Putra \& Rahyuda (2015), Khuong \& Yen (2016), Putri \& Rahyuda (2019) and Hastutiningsih (2019) which state that the work environment indirectly affects employee performance through work stress.

\section{CONCLUSION}

Workload has a positive and insignificant effect on crew performance PT. Indonusa Tenggara Marine. The work environment has a positive and insignificant effect on crew performance PT. Indonusa Tenggara Marine. Workload has a positive and significant effect on crew work stress of PT. Indonusa Tenggara Marine. Work Environment has a negative and significant effect on crew work stress of PT. Indonusa Tenggara Marine. Work stress has a negative and significant effect on crew performance PT. Indonusa Tenggara Marine.
Work stress is a perfect mediation for workload on crew performance PT. Indonusa Tenggara Marine, it means work stress able to perfectly explain the effect of workload on crew performance of PT. Indonusa Tenggara Marine. Work stress is a perfect mediation for work environment on crew performance PT. Indonusa Tenggara Marine, therefore work stress able to perfectly explain the effect of work environment on crew performance PT. Indonusa Tenggara Marine.

\section{REFERENCES}

Abbasi, M. M., \& Janjua, S. Y. (2016). The Mediating Effect of Job Stress on Work Overload and Organizational Performance in the Banking Industry. Abasyn Journal of Social Sciences, 9(2), 376-387.

Ahmad, E. H., Maidin, A., Abdullah, T., Naiem, F., Buraerah, S., Handayanif, R., \& Prihantono, P. (2018). Relationship of Work Stress to the Performance of Intensive Care Unit Nurses in Makassar. American Journal of Public Health Research, 6(1), 18-20.

Akob, M. (2016). Influence Workload, Work Ethic and Job Satisfaction toward Teacher's Performance (Study of Islamic-based School in Makasar-Indonesia). Global Advanced Research Journals of Management and Business Studies, 5(7), 172-177.

Al-Omari, K., \& Okasheh, H. (2017). The influence of work environment on job performance: A case study of engineering company in Jordan. International Journal of Applied Engineering Research, 12(24), 15544-15550.

Alkubaisi, M. M. (2015). How can Stress Affect Your Work Performance? Quantitative Field Study on Qatari Banking Sector. Business and Management Research, 4(1), 99-109.

An, J., Liu, Y., Sun, Y., \& Liu, C. (2020). Impact of work-family conflict, job stress and job satisfaction on seafarer performance. International Journal of Environmental Research and Public Health, 17(7).

Angwen, D. G. (2017). Hubungan Antara Lingkungan Kerja Fisik dan Beban Kerja Dengan Stres Kerja Pada Pt Panggung Electric Citrabuana. Calyptra: Jurnal Ilmiah Mahasiswa Universitas Surabaya, 6(2), 577-586.

Bahri, S., Zaki, M., \& Zulkarnain, F. (2018). Pengaruh Organizational Citizenship Behaviour (OCB) dan Lingkungan Kerja Terhadap Kinerja Pegawai Melalui Stres Kerja Pada PT. PLN (Persero) Unit Induk Pembangunan Bagian Utara. Jurnal Manajemen, 200-208.

Boxall, P., Purcell, J., \& Wright, P. (2007). The Oxford Handbook of Human Resource Management. 
Oxford University Press.

Chandra, R., \& Adriansyah, D. (2017). Pengaruh Beban Kerja Dan Stres Kerja Terhadap Kinerja Karyawan Pada Pt. Mega Auto Central Finance Cabang Di Langsa. Jurnal Manajemen Dan Keuangan, 4(2), 670-678.

Dharmanegara, I. B. A., Sitiari, N. W., \& Wirayudha, I. D. G. N. (2016). Job Competency and Work Environment: the effect on Job Satisfaction and Job Performance among SMEs Worker. IOSR Journal of Business and Management (IOSRJBM). Vol. 18. Issue 1.Ver. II: 19-26. IOSR Journal of Business and Management (IOSRJBM), 18(1), 19-26.

Ekawarna. (2018). Manajemen Konflik dan Stres. PT. Bumi Aksara.

Erawati, K. N., Sitiari, N. W., \& Indiani, N. L. P. (2019). The Effect of Stress and Working Environment on Employee Performance through Motivation Mediation: A Case Study on International Restaurant in Badung Bali. Jurnal Ekonomi Dan Bisnis Jagaditha, 6(1), 2230.

Ghozali, I., \& Latan, H. (2014). Partial Least Square Konsep, Teknik dan Aplikasi Menggunakan Program Smart PLS 3.0. Badan Penerbit Universitas Diponegoro.

Gozali, N. (2016). The Influence of Workload and Individual Characteristic on Job Satisfaction and Its Impact on Employee Performance (A Case Study at Indonesian Regional Statistics Office (BPS) of Deli Serdang and Serdang Bedagai Regencies). Jurnal Bisnis Dan Manajemen Eksekutif, 1(1), 39-46.

Hamid, N. Z. A., \& Hassan, N. (2015). The Relations Betwen Workplace Environments and Job Perpormance in Selected Goverment Office in Selangor Malaysia. International Review of Management and Business Research, 4(3), 845851.

Harini, S., \& Kartiwi, N. (2018). Workload , Work Environment and Employee Performance of Housekeeping. International Journal of Latest Engineering and Management Research (IJLEMR), 03(10), 15-22.

Hastutiningsih, A. T. (2019). Pengaruh beban kerja dan lingkungan kerja terhadap kinerja karyawan dimediasi stres kerja. Prosiding National Conference on Applied Business.

Hatmawan, A. A. (2015). Pengaruh Konflik Kerja, Beban Kerja serta Lingkungan Kerja Terhadap Stres Pegawai PT. PLN (Persero) Area Madiun Rayon Magetan. Assets: Jurnal Akuntansi Dan Pendidikan, 4(1), 91-98.

Johari, J., Yean Tan, F., \& Tjik Zulkarnain, Z. I. (2018). Autonomy, workload, work-life balance and job performance among teachers. International Journal of Educational
Management, 32(1), 107-120.

Kasmir. (2019). Manajemen Sumber Daya Manusia. Rajawali Pers.

Khuong, M. N., \& Yen, V. H. (2016). Investigate the Effects of Job Stress on Employee Job Performance - A Case Study at Dong Xuyen Industrial Zone, Vietnam. International Journal of Trade, Economics and Finance, 7(2), 31-37.

Kristanti, E. (2017). Pengaruh Lingkungan Kerja Fisik dan Lingkungan Kerja Non Fisik Terhadap Stres Kerja dan Dampaknya Terhadap Kinerja Karyawan (Studi Pada Kantor Bersama Samsat Mojokerto Kota). Jurnal Ilmu Manajemen, 5(1), $1-10$.

Lestari, E. E. D., \& Ratnasari, S. L. (2018). Pengaruh Konflik Interpersonal, Beban Kerja dan Komunikasi Terhadap Stres Kerja Karyawan PT. Viking Engineering Batam. Jurnal Trias Politika, 2(2), 163-177.

Putra, I. B. K. S. D., \& Rahyuda, A. G. (2015). Pengaruh Lingkungan Kerja Fisik Dan Stres Kerja Terhadap Kinerja Pegawai Di Upt. Pengujian Kendaraan Bermotor Dinas Perhubungan Kota Denpasar. E-Jurnal Manajemen Universitas Udayana, 4(9), 24912506.

Putri, N. M. S. R., \& Rahyuda, A. G. (2019). Peran Stres Kerja Dalam Memediasi Pengaruh Beban Kerja dan Lingkungan Kerja terhadap Kinerja Karyawan. E-Jurnal Manajemen, 8(12), 73707390.

Robbins, S. P., \& Judge, T. A. (2019). Perilaku Organisasi. Salemba Empat.

Shabbir, B., \& Naqvi, R. (2017). Impact of Workload and Job Complexity on Employee Job Performance with the Moderating Role of Social Support and Mediating Role of Job Stress: A Study of Travel agencies in Rawalpindi, Islamabad and AJK. Journal of Accounting \& Marketing, 06(01), 1-7.

Siagian, S. P. (2018). Manajemen Sumber Daya Manusia. Bumi Aksara.

Siswanto, S., Supriyanto, A. S., Ni'mah, U., Asnawi, N., \& Wekke, I. S. (2019). Does a workload influence the performance of bank employees? Management Science Letters, 9(5), 639-650.

Sugiyono. (2019). Metode Penelitian Kuantitatif. Alfabeta.

Susiarty, A., Suparman, L., \& Suryatni, M. (2019). the Effect of Workload and Work Environment on Job Stress and Its Impact on the Performance of Nurse Inpatient Rooms At Mataram City General Hospital. Scientific Research Journal, VII(VI).

Sutrisno, E. (2019). Manajemen Sumber Daya Manusia. Kencana.

Tharenou, P., Donohue, R., \& Cooper, B. (2007). Management Research Methods. Cambridge 
University Press.

Tjahjaningsih, E., Hayuningtias, K. A., Santoso, I. H., \& Syadly, G. M. (2019). The Role of Work Environment on Bank Employees' Performance. Advances in Economics, Business and Management Research, 86(Icobame 2018), 127-130.

Tjibrata, F. R., Lumanaw, B., \& Dotulang O.H, L. (2017). Pengaruh Beban Kerja Dan Lingkungan Kerja Terhadap Kinerja Karyawan PT.Sabar Ganda Manado. Jurnal EMBA, 5 No.2(Juni), $1570-1580$.

Wibowo. (2017). Manajemen Kinerja. Rajawali Pers.

Wibowo. (2019). Perilaku Dalam Organisasi. Rajawali Pers.

Yoga, I. K. D. P., Sitiari, N. W., \& Sara, M. (2018). The Effect of Organizational Culture on Employee Performance Mediated by Work Stress: Study at PT ADIRA Dinamika
Multifinance in Denpasar. Jurnal Ekonomi Dan Bisnis Jagadhita, 5, 97-108.

Yosiana, Y., Hermawati, A., \& Mas'ud, M. H. (2020). The Analysis of Workload and Work Environment on Nurse Performance with Job Stress as Mediation Variable. Journal of Socioeconomics and Development, 3(1), 37.

Yugusna, I., Azis Fathoni, \& Haryono, A. T. (2016). Pengaruh Gaya Kepemimpinan Demokratis Dan Lingkungan Kerja Terhadap Kinerja Dan Kedisiplinan Karyawan. Journal of Management, 2(2), 23.

Zulmaidarleni, Sarianti, R., \& Fitria, Y. (2019). Pengaruh Beban Kerja dan Lingkungan Kerja Fisik Terhadap Stres Kerja pada Pegawai Kantor Kecamatan Padang Timur. Jurnal Eco Gen, 2 Nomor 1(Maret), 61-68. 